\title{
PELAKSANAAN BESTUURSDWANG DALAM BIDANG PERIZINAN (Suatu Studi Dalam Konteks Hukum Lingkungan)
}

\section{Oleh :}

\author{
W.M. Herry Susilowati
}

\begin{abstract}
License is an instrument that the most widely used in public administration law. The implementation of administrations sanction (bestuursdwang) therefore enable the government to take the administrative action effectively and preventively, It is one of government discretion authority.

The instrument has stabilizer, perfective and corrective function to make everyone who conflict or break the law to end their action. Bestuursdwang is the most important law enforcement as it is very effective 'real action' (feitelijkhandellingen) that government could make to end the conditions that is prohibited in administrative law. The dissatisfied or suffered party is able to submit beschikking to be examined in PTUN. In this content, the judge will act as the invention of law, the former of law, the innovator of law and the executor of law and the fortification of justice. That also happens in living space conservation.
\end{abstract}

Keywords : Public administration law, discretion authority, law enforcement.

\section{PENDAHULUAN}

Dewasa ini semakin disadari, dengan munculnya konsepsi negara hukum modern (welfarestate) di Eropa Barat pada permulaan abad ke-20, yang mengutamakan kesejahteraan rakyat, telah membawa konsekuensi bagi campur tangan administrasi negara yang semakin luas, sejalan dengan tugas melaksanakan servis publik yang sangat kompleks dan memasuki hampir semua aspek kehidupan; sehingga tidak jarang kita mengalami kesukaran tentang batas-batas ruang lingkup tugas dari administrasi negara itu sendiri.

Indonesia yang juga sebagai penganut konsepsi welfarestate (negara kesejahteraan) tentunya tidak terlepas membawa pengaruh bagi keleluasaan administrasi negara dalam rangka pelayanan kepada masyarakat. Bahkan kepada administrasi negara diberikan kebebasan untuk atas inisiatif sendiri melakukan perbuatan-perbuatan guna menyelesaikan persoalan-persoalan yang mendesak, yang belum ada aturan dalam rangka penyelesaiannnya (fries ermessen).

Namun demikian, keleluasaan dimaksud tersebut tidaklah bersifat mutlak, tetapi sejalan dengan konstitusi, Indonesia sebagai negara hukum (rechtstaat), segala tindakan administrasi negara 
harus tetap dapat dipertanggung-jawabkan secara yuridis, bahkan secara moral kepada Tuhan Yang Maha Esa. (Sjachran Basah: 1992 : h. 3-4)

Dari konstelasi yang demikian, maka untuk melaksanakan tugas administrasi tersebut muncul berbagai instrumen yang dapat digunakan sebagai sarana pendukung tugas mereka yang sangat kompleks. Di samping instrumen tradisional seperti ketentuan memerintah dan melarang dalam perundangan dalam arti formal dan dalam algemene maatregelen van bestuur dan verordeningen (Spelt, N.M. dan Ten Berge J.B.J.M; 1993 :h. 1), digunakan sarana-sarana lain dalam rangka penyelenggaraan servis publik. Ini berlaku bagi instrumen seperti sistem subsidi dan perizinan.

Dalam praktiknya, izin merupakan salah satu instrumen yang paling banyak digunakan dalam hukum administrasi negara. Hal ini dapat kita lihat dari kenyataan bahwa peraturan perundang-undangan baik yang dibuat pemerintah pusat maupun pemerintah daerah mewajibkan setiap warga yang ingin melakukan suatu usaha, diharuskan memperoleh izin lebih dahulu dari pemerintah pusat atau pemerintah daerah, yang tentunya dengan berbagai persyaratanpersyaratan yang harus dipatuhi.

Oleh sebab itu untuk penegakan hukumnya (law enforcement) diperlukan sebagai sanksi, baik perdata, pidana maupun administratif terhadap warga masyarakat yang telah melanggar izin yang diberikan, karena pada umumnya tidak akan ada artinya memasukkan kewajiban-kewajiban atau laranganlarangan bagi para warga di dalam peraturan perundang -undangan tata usaha negara, manakala aturan-aturan tingkah laku itu tidak dapat dipaksakan oleh tata usaha negara (dalam hal dimaksud diperlukan). (Phlipus M. Hadjon ; 1993 ; h.245)

Realitas ini menunjukkan bahwa sanksi administratif (bestuursdwang), penutupan perusahaan, larangan memakai peralatan tertentu, uang paksa (dwangsom) dan penarikan izin (Hamzah, A ; 1995 ; h. 107), mempunyai peranan sebagai tindakan preventif yang sangat efektif terhadap penegakan hukum.

Hal ini berarti bestuursdwang sebagai salah satu bentuk sanksi administratif mempunyai peranan yang sangat urgen, karena merupakan tindakan yang nyata (feitelijkehandelingen) dari penguasa guna mengakhiri suatu keadaan yang dilarang oleh suatu kaidah hukum administrasi atau (bila masih) melakukan apa yang seharusnya ditinggalkan oleh para warga karena bertentangan dengan undangundang, (Philipus M. Hadjon ; 1993 ; h. 246) termasuk yang ada kaitannya pada suatu izin.

Berdasarkan latar belakang penulisan yang dikemukakan, berarti dalam membicarakan perizinan, kita tidak bisa terlepas dari paksaan pemerintahan (bestuursdwang) sebagai salah satu instrumen administratif bagi perlindungan kepentingan yang seharusnya dijaga oleh ketentuan yang dilanggar.

Berdasarkan hal tersebut untuk mewujudkan 
arah dan tujuan penulisan ini, maka dirumuskan identifikasi masalah untuk dijadikan sebagai batasan dan tolok ukur pembahasan sebagai berikut :

1. Bagaimanakah penerapan paksaan pemerintahan (bestuursdwang) sebagai instrumen administratif dalam bidang perizinan, khususnya akibat pelanggaran terhadap ketentuan hukum lingkungan?

2. Dengan diterapkannya paksaan pemerintahan (bestuursdwang) tersebut, bagaimana konsekwensinya bagi para pihak yang dirugikan akibat keputusan tersebut?

\section{PEMBAHASAN}

Pembukaan UUD 1945 secara tegas menyebutkan bahwa tujuan kehidupan bernegara kita adalah untuk melindungi segenap bangsa Indonesia dan seluruh tumpah darah Indonesia, memajukan kesejahteraan umum (cetak tebal, penulis), mencerdaskan kehidupan bangsa dan ikut melaksanakan ketertiban dunia yang berdasarkan kemerdekaan, perdamaian abadi dan keadilan sosial. Hal ini secara konstitusional menunjukkan bahwa negara Republik Indonesia merupakan penganut konsepsi negara hukum modern (welfare state).

Guna mewujudkan hal demikian, tentunya membawa pengaruh bagi keterlibatan administrasi negara yang sangat besar dalam berbagai aspek kehidupan, seperti halnya dalam bidang kesejahteraan sosial ekonomi dan pemeliharaan kesehatan. Kondisi ini menyebabkan organ penguasa memerlukan wewenang-wewenang baru dan instrumen-instrumen lain yang mendukung pelaksanaan tugasnya, sehingga muncul berbagai instrumen-instrumen pemerintahan seperti dispensasi, izin, lisensi dan konsesi.(Djenal Hoesen Koesoumahatmadja ; 1979 ; h.90).

Namun demikian, dalam negara hukum demokratis, penguasa tidak dapat menggunakan instrumen-instrumen yang tersedia baginya tanpa batas dan tanpa syarat. Karena itu pengaruh-pengaruh dari masyarakat atas penguasa tidak hanya (ikut) bertanggung jawab atas bertambahnya tugas-tugas penguasa dan dengan itu berkembangnya instrumeninstrumen penguasa, namun sekaligus memberi batasan bagi penggunaannya. Aturan-aturan yang menjadi dasar diadakan pembatasan atas wewenang penguasa, telah ditetapkan dalam hukum tata negara dan hukum administrasi. (Spelt, N.M. dan Ten Berge)

Bila diperhatikan dalam praktiknya, izin memegang peranan penting dalam penyelenggaraan pemerintahan, karena dapat dijadikan sebagai sarana yuridis untuk mengemudikan tingkah laku para warga.

Hal ini sejalan dengan pandangan Sjachran Basah, yang menyebutkan bahwa izin adalah merupakan ujung tombak dari instrumen hukum, yang mengaplikasikan peraturan dalam hal konkreto di semua sektor kehidupan yang beraneka ragam.(Sjachran Basah; 1992; h.4).

Tentunya izin sebagai perbuatan administrasi ini dalam mengaplikasikan peraturan dalam hal 
konkreto berdasarkan persyaratan dan prosedur sebagaimana ditetapkan oleh ketentuan perundangundangan yang berlaku,yang menimbulkan hak dan kewajiban bagi warga masyarakat.

Bahkan dalam konteks hukum lingkungan bila ditelusuri ketentuan Undang-undang No. 4 Tahun 1982 tentang Ketentuan-ketentuan Pokok Pengelolaan Lingkungan Hidup, dalam pasal 7 menyebutkan tentang persyaratan yang harus dicantumkan dalam setiap izin yang dikeluarkan oleh instansi yang berwenang, yaitu kewajiban untuk memelihara kelestarian kemampuan lingkungan hidup yang serasi dan seimbang untuk menunjang pembangunan yang berkesinambungan.

Dengan demikian menurut Siti Sundari Rangkuti, bahwa:

setiap instansi yang berwenang di bidang perizinan secara selektif memberikan izin bagi kegiatan dan tempat usaha yang menimbulkan dampak terhadap lingkungan hidup, dengan atau tanpa persyaratan (pertimbangan lingkungan), yang memungkinkan dikenakannya sanksi administratif.(Rangkuti, Siti Sundari ; 1992 ; h.11).

Oleh sebab itu bila diperhatikan penegakan hukum lingkungan, perlu diketahui bahwa peraturan tentang lingkungan mempunyai dua sisi. Satu sisi merupakan kaidah atau norma, sedangkan di sisi lain adanya instrumen yang merupakan alat untuk mempertahankan, mengendalikan dan menegakkan kaidah (norma) tersebut, berupa sanksi.

Bila diperhatikan lebih lanjut, dikenal adanya tiga instrumen utama dalam menegakkan hukum lingkungan, yaitu instrumen administratif, instrumen perdata dan instrumen pidana.(Hamzah A.,h.20)

Instrumen administratif mempunyai peranan yang sangat urgen, karena merupakan tindakan pencegahan (preventif) yang bertujuan agar perbuatan yang melanggar hukum atau tidak memenuhi persyaratan berhenti atau mengembalikan kepada keadaan semula.

Dalam hal ini dikenal beberapa jenis sarana penegakan hukum administratif, yaitu berupa : (Rangkuti, Siti Sundari; h.20).

a. Teguran lisan atau tertulis :

b. Tindakan paksa (Bestuursdwang) :

c. uang paksa (Publiekrechtelijke dwangsom):

d. penutupan tempat usaha (Sluiting van een inrichting) :

e. Penghentian kegiatan mesin perusahaan (Buitengebruikstelling van een toestel)

f. Pencabutan izin melalui proses : teguran, paksaan kepolisian, penutupan dan uang paksa.

Dari berbagai instrumen administratif tersebut, tindakan paksa (Bestuursdwang) merupakan Feitelijkehandeling penguasa untuk menyesuaikan situasi tidak sah, yang terjadi karena suatu kewajiban yang timbul dari norma hukum administrasi, termasuk ketentuan-ketentuan izin.

Meskipun demikian, tentunya paksaan 
pemerintahan itu harus memenuhi persyaratan tertentu, sehingga tidak terjadi kesewenang-wenangan penguasa yang pada gilirannya dapat menimbulkan kerugian bagi warga masyarakat. Konsekuensinya akan terjadi gugatan kepada administrasi negara bersangkutan, baik yang bersifat perdata atau pun tata usaha negara.

Hal ini menunjukkan bahwa dewasa ini semakin diperlukan kajian terhadap paksaan pemerintahan, terutama dilihat dalam hubungannya dengan asa-asas umum pemerintahan yang baik, yang apada gilirannya diperoleh suatu solusi atas perlindungan hukum, baik terhadap sikap tindak administrasi negara mau pun warga masyarakat.

Dalam melakukan studi atas pelaksanaan bestuursdwang dalam bidang perizinan ini, penulis menggunakan pendekatan yuridis-empiris dan analitik. Berdasarkan pendekatan ini penulis terlebih dahulu meninjau kedudukan bestuursdwang dari pendekatan hukum administrasi. Selanjutnya dilakukan pembahasan dengan mempergunakan beberapa kasus yang bersifat empirik.

Sedangkan pendekatan analitik dalam studi ini dimaksudkan untuk memberi gambaran penerapan bestuursdwang dalam hubungannya dengan izin serta konsekuensi yang ditimbulkannya, terutama bagi warga masyarakat yang merasa dirugikan.
Tinjauan Umum Tentang Instrumen Hukum Administratif Sebagai Sarana Penegakan Hukum

Di Indonesia dapat kita perhatikan bahwa sarana penegakan hukum ( law enforcement, rechtshandeling) terdiri dari instrumen administratif, instrumen perdata mau pun instrumen hukum pidana dan tata usaha negara.

Salah satu upaya penegakan hukum yang terpenting adalah melalui instrumen hukum administratif, karena bersifat preventif dan bertujuan agar perbuatan atau pengabaian yang melanggar hukum atau tidak memenuhi persyaratan, berhenti atau mengembalikan kepada keadaan semula. Jadi fokus sanksi administratif ialah perbuatannya, berbeda dengan sanksi hukum pidana yang ditujukan kepada pembuatnya (orang-orang).

Dalam hal ini diantara para sarjana masih terdapat perbedaan pendapat tentang jenis-jenis sanksi administratif, Philipus M. Hadjon, dkk., menyebutkan sanksi hukum administrasi adalah bersifat khas, yang meliputi :

a. Bestuursdwang (paksaan pemerintahan);

b. Penarikan kembali keputusan (ketetapan) yang menguntungkan ( izin, pembayaran, subsidi);

c. Pengenaan denda administratif ;

d. Pengenaan uang paksa oleh pemerintah (dwangsom).(Philipus M. Hadjon., h. 246). Sedangkan A. Hamzah dalam bukunya " Penegakan Hukum Lingkungan ", menyebutkan 
bahwa sanksi administratif terdiri dari : paksaan administratif, penutupan usaha, uang paksa (dwangsom) dan penarikan izin.(Hamzah A., h.107).

Sementara itu Siti Sundari Rangkuti, sebagaimana dikemukakan sebelumnya menyebutkan beberapa jenis sarana penegakan hukum administratif sebagai berikut :

a. Teguran lisan dan atau tertulis;

b. Tindakan paksa (Bestuursdwang);

c. Uang paksa(Publiekrechtelijke dwangsom) ;

d. Penutupan tempat usaha (Sluiting van een inrichting);

e. Penghentian kegiatan mesin perusahaan (Buitengebruikstelling van een toestel);

f. Pencabutan izin melalui proses : teguran, paksaan kepolisian, penutupan dan uang paksa.

Dari beberapa pandangan tersebut, maka menurut hemat penulis secara umum instrumen hukum administratif adalah meliputi : paksaan pemerintahan (bestuursdwang), pengenaan denda administratif, uang paksa (dwangsom) dan penarikan izin.

\section{Paksaan Pemerintahan (Bestuursdwang)}

Paksaan pemerintahan atau disebut juga paksaan administratif adalah merupakan wewenang organ pemerintahan untuk menyesuaikan situasi yang tidak sah, tidak ditunaikan dengan nyata. Termasuk hukum administrasi yang dipahami secara umum, juga ketentuan-ketentuan tentang izin.

Ini berarti bahwa pelaksanaan bestuursdwang adalah suatu wewenang, bukan kewajiban.(Philipus M. Hadjon.,h.252)Ciri khas dari wewenang paksaan administratif ini adalah bahwa ia membuat organ pemerintahan berwenang untuk bila perlu, tanpa keharusan perantaraan hakim terlebih dahulu, bertindak jauh secara nyata.(Spelt,N.M. dan Ten Berge., h.75).

Berdasarkan hal demikian, maka sebelum menjalankan bestuursdwang, badan pemerintahan wajib mempertimbangkan semua kepentingan yang terkait, dan sedapat mungkin diberitahukan secara tertulis kepada si pelanggar dengan didahului peringatan, sehingga pihak yang diberi peringatan memperoleh kesempatan memperbaiki atau mengakhiri sendiri pelanggaran atas norma hukum yang dilakukannya. Hal ini terutama ditujukan pada akibat hukum yang ditimbulkan oleh bestuursdwang yang merupakan keputusan tata usaha negara, yang tentunya dapat diuji oleh hakim administrasi.

Oleh sebab itu ada beberapa hal yang harus dipertimbangkan dalam menerapkan bestuursdwang, (Philipus M. Hadjon., 252-253) yakni :

Pro Bestuursdwang

1. Kepentingan umum yang dirugikan oleh keadaan ilegal ( misalnya : pencemaran lingkungan ).

2. Kepentingan pencegahan (pengelakan) pengaruh preseden. Disini harus diingat bahwa asas persamaan ( gelijkheidsbeginsel) membawa 
serta bahwa tata usaha negara tidak membiarkan begitu saja perilaku seseorang, bila ia tidak menghendakinya dari yang lain. Lagi pula suatu preseden mempunyai daya pengaruh bagi para pelanggar dan pelanggaran-pelanggaran baru.

3. Kepentingan pihak ketiga ( biasanya bagi orangorang yang diam disekitarnya). Orang-orang itu berkepentingan bahwa penguasa bertindak dalam hal pendirian bangunan-bangunan liar, kegiatan ilegal yang amat mengganggu, keadaan-keadaan berbahaya yang dilarang, dan sebagainya.

\section{Kontra Bestuursdwang}

1. Kepentingan dari pelanggar dengan dipertahankannya keadaan yang ilegal. Dapat dibayangkan terjadinya pemusnahan modal jika diputuskan untuk menggusur sebuah bangunan. Juga dapat dibayangkan kepentingan pelanggar dalam hal mata pencahariannya.

2. Masalah-masalah praktis atau ketidak mungkinan. Bestuursdwang tidak praktis misalnya berkenaan dengan suatu larangan penyriman kebun dengan air minum. Bukankan orang-orang melakukannya dengan hanya menutup kran.

3. Pembiayaan yang tinggi dari bestuursdwang. Benar biaya dapat dibebankan kepada para pelanggar, namun bisa terjadi biaya akan melambung secara tidak seimbang. Kadang kala dapat pula diperkirakan bahwa biaya akan tetap dipikul oleh penguasa karena melanggar tidak membayamya.
4. Jika perlu ditindak sesuai dengan hukum pidana. Dari realitas tersebut, maka dalam penerapan instrumen paksaan administratif, penguasa disamping memperhatikan norma perundangundangan yang berlaku, juga harus memperhatikan asas-asas umum pemerintahan yang baik.

\section{Denda Administratif}

Denda administratif adalah sanksi yang dikenakan kepada warga masyarakat yang tidak melaksanakan kewajibannya sebagimana ditetapkan dalam undang-undang, dan biasanya pelaksanaannya dilakukan melalui Surat tagihan, dan bila diperlukan dapat melalui surat paksa. Besarnya denda administratif tersebut biasanya sudah ditetapkan dalam peraturan perundangan yang bersangkutan.

Hal ini misalnya terlihat dalam pasal 11 ayat 3 dan 4 Undang-undang no. 12 tahun 1994 tentang Perubahan Atas Undang-undang no.12 tahun 1985 tentang Pajak Bumi dan Bangunan, menyebutkan :

(3) Pajak yang terhutang yang pada saat jatuh tempo pembayaran tidak dibayar atau kurang dibayar, dikenakan denda administrasi sebesar $2 \%$ (dua persen) sebulan, yang dihitung dari saat jatuh tempo sampai dengan hari pembayaran untuk jangka waktu paling lama 24 ( dua puluh empat) bulan.

(4) Denda administrasi sebagaimana dimaksud 
dalam ayat (30 ditambah dengan hutang pajak yang belum atau kurang dibayar ditagih dengan surat tagihan pajak yang harus dilunasi selambat-lambatnya 1 (satu) bulan sejak tanggal diterimanya Surat Tagihan Pajak oleh wajib pajak.

\section{Uang Peksa (Dwangsom)}

Pengenaan uang paksa adalah merupakan alternatif kepada badan yang berwenang sebagai pengganti bestuursdwang.(Spelt, N.M. dan Tan Berge., h,85).Hal ini dimaksudkan dengan mempertimbangkan bahwa dalam keadaan tertentu bestuursdwang secara praktis sulit dijalankan, atau bila hal tersebut dijalankan akan berlaku sebagai suatu sanksi yang terlalu berat.

Dari hubungan ini dapat disimpulkan bahwa uang paksa, meskipun berbeda dengan paksaan pemerintahan dan terutama bersifat preventif, tidak boleh dipakai sebagai upaya terhadap pelanggaran. Uang paksa hanya boleh dibebankan, jika pada dasarnya paksaan pemerintahan juga dapat diterapkan. Di Indonesia uang paksa sebagai sanksi administratif belum dikenal dalam hukum lingkungan.(Hamzah, A., h.111)

\section{Penarikan Izin}

Penarikan kembali izin sebagai suatu sanksi adalah merupakan keputusan (beschiking) akibat tidak dipatuhinya pembatasan-pembatasan atau ketentuan-ketentuan yang terkait pada keputusan pemberian izin tersebut serta akibat tidak dipenuhinya ketentuan dalam undang-undang.

Dari hal tersebut di atas, maka pada umumnya ada 2 (dua) hal yang menyebabkan suatu keputusan yang menguntungkan dapat ditarik kembali sebagai sanksi: (Philipus M. Hadjon ; h.258-259).

a. Yang berkepentingan tidak mematuhi pembatasan-pembatasan, syarat-syarat atau ketentuan peraturan perundang-undangan yang dikaitkan pada izin, subsidi, atau pembayaran.

b. Yang berkepentingan pada waktu mengajukan permohonan untuk mendapat izin, subsidi, atau pembayaran telah memberikan data yang sedemikian tidak benar atau tidak lengkap, hingga apabila data itu diberikan secara benar atau lengkap maka keputusan akan berlainan (misalnya: penolakan izin, dsb).

Oleh sebab itu bila diperhatikan penarikan kembali izin sebagai suatu sanksi, pada kenyataannya juga merupakan suatu perbuatan keputusan (beschikking) baru, yang menarik kembali (menyatakan tidak berlaku lagi baik untuk seluruhnya maupun untuk sebagian) keputusan yang terdahulu.

Hal ini tentunyajuga mempunyai konsekuensi bahwa keputusan penarikan kembali izin sebagai sanksi dapat menimbulkan akibat hukum yang baru bagi seorang warga atau badan hukum perdata yang dikenai keputusan itu.

Memperhatikan keadaan demikian, pejabat 
tata usaha negara seharusnya berhati-hati dalam menerapkan sanksi tersebut, karena hal ini akan berakibat apabila seseorang atau badan hukum perdata merasa dirugikan akibat keputusan penarikan kembali izin sebagai sanksi, maka mereka dapat menggunakan upaya hukum melalui Peradilan Tata Usaha Negara.

Penerapan Paksaan Pemerintahan (Bestuursdwang) sebagai Instrumen Administratif Dalam Bidang Perizinan Sebagai Akibat Penglanggaran Hukum Lingkungan.

Sebagaimana dikemukakan terdahulu, bahwa pada umumnya tidak akan ada gunanya membuat suatu ketentuan yang berisi kewajiban-kewajiban atau larangan-larangan bagi warga masyarakat dalam peraturan perundang-undangan, manakala aturanaturan tingkah laku itu tidak dapat dipaksakan penegakannya oleh pejabat yang berwenang.

Demikian juga halnya dengan perizinan, tidak akan ada manfaatnya, apabila berbagai kewajiban yang ditentukan didalamnya tidak dapat dipaksakan, jika terhadapnya terjadi pelanggaran-pelanggaran oleh pemegang izin. Apalagi dewasa ini dalam mewujudkan pembangunan yang berkelanjutan hampir pada setiap pemberian izin diwajibkan memelihara kelestarian kemampuan lingkungan hidup yang serasi dan seimbang sebagai salah satu persyaratan yang harus dipenuhi.

Memperhatikan hal tersebut, penerapan sanksi baik melalui instrumen administratif, instrumen perdata maupun instrumen hukum pidana merupakan conditio sine quanon dalam penegakan hukum (law enforcement).

Hal ini sejalan dengan pandangan Sjachran Basah, yang menyebutkan adanya panca fungsi hukum dalam masyarakat, sebagai berikut : (Sjachran Basah ; 1986; h. 24-25).

1. Direktif, sebagai pengarah dalam membangun untuk membentuk masyarakat yang hendak dicapai sesuai dengan tujuan kehidupan bernegara.

2. Integratif, sebagai pembina kesatuan bangsa.

3. Stabilitatif, sebagai pemelihara (termasuk kedalamnya hasil-hasil pembangunan) dan penjaga keselarasan, keserasian dan keseimbangan dalam kehidupan bernegara dan bermasyarakat.

4. Perfektif, sebagai penyempurna terhadap tindakan-tindakan administrasi negara, maupun sikap tindak warga dalam kehidupan bernegara dan bermasyarakat.

5. Korektif, baik terhadap warga negara maupun administrasi negara dalam mendapatkan keadilan.

Melihat konstruksi yang demikian, maka penegakan hukum melalui instrumen hukum administratif merupakan fungsi stabilitatif, perfektif dan korektif, yang bertujuan agar perbuatan atau pengabaian yang melanggar hukum atau tidak 
memenuhi persyaratan, berhenti atau mengembalikan pada keadaan semula ( sebelum terjadinya pelanggaran).

Dalam hal ini instrumen administratif sebagai pengendalian perbuatan terlarang yang ditujukan kepada perlindungan kepentingan yang dijaga oleh ketentuan yang dilanggar. Dari berbagai jenis sanksi administratif tersebut, upaya paksa pemerintahan ( bestuursdwang ) merupakan sarana penegakan hukum yang terpenting karena merupakan tindakan nyata ( Feitelijkhandelingen ) dari penguasa yang sangat efektif guna mengakhiri suatu keadaan yang dilarang oleh suatu kaidah hukum administrasi atau masih melakukan apa yang seharusnya ditinggalkan oleh para warga disebutkan bertentangan dengan undang-undang.

Realitas ini antara lain terlihat dari Surat Perintah Bupati KDH Tk. II Sukabumi, yang memerintahkan penghentian sementara penambangan bahan galian golongan $\mathrm{C}$ disebabkan tidak dipenuhi berbagai persyaratan yang sudah ditentukan, khususnya menyangkut persyaratan teknis berkenaan dengan pemeliharaan lingkungan hidup, sebagaimana tertuang dalam konsideran Surat Perintah tersebut :

a. Bahwa penambangan bahan galian golongan $\mathrm{C}$ di Desa Titisan dan Cimangkok, kegiatan usahanya tidak memenuhi ketentuan teknis yang baik dan benar sehingga menimbulkan pencemaran/pelumpuran terhadap Kali Cikupa dan sekitarnya ; b. Bahwa air dari Kali Cikupa Kecamatan Sukaraja, sampai saat ini sangat dibutuhkan untuk dipergunakan bagi kehidupan masyarakat dan alam sekitarnya.

c. Bahwa Kali Cikupa merupakan daerah tangkapan air bagi daerah sekitarnya, maka dipandang perlu adanya tindakan perlindungan pengamanan fungsinya ;

d. Bahwa dalam rangka melindungi Kali Cikupa dari kegiatan penambangan dan pencucian pasir yang mengganggu dan merusak kualitas air kali, kondisi fisik dan dasar kali serta mengamankan aliran Kali Cikupa, sehingga dipandang perlu dikeluarkan Surat Perintah Bupati KDH Tk. II Sukabumi untuk pembuatan/pembangunan Waste Disposal dan paritannya.(SP. Bupati Kepala Daerah TK.II No. $545 / 1662 / 1992$ )

Selanjutnya dalam Surat Perintah tersebut pada butir 6 terkandung paksaan pemerintahan, yang menyebutkan bahwa sebelum seluruh sitem diatas berfungsi baik, dilarang adanya penambangan dan pencucian pasir.

Demikian juga halnya dengan lahimya Surat Keputusan Gubernur KDH Tk, I Jawa Barat nomor ; 540/Sk.983/Distamb/93 Tentang Penutupan Kegiatan Usaha Pertambangan Pada Badan dan Bantaran Sungai Cipamingkis ( terlampir), disebabkan adanya penambangan yang tidak memenuhi persyaratan teknis yang menyebabkan terjadinya kerusakan-kerusakan yang menimbulkan 
dampak negatif terhadap lingkungan sungai.

Kondisi tersebut disebabkan pemegang Surat Izin Penambangan Daerah (SIPD) tidak memenuhi kewajibannya, yaitu memelihara lingkungan hidup dan mencegah serta menanggulangi kerusakan dan pencemaran, sesuai dengan peraturan perundangundangan yang berlaku serta mengikuti petunjuk dari Dinas dan instansi lain yang berwenang .

Dari konstelasi yang demikian, menunjukkan bahwa izin sebagai perbuatan administrasi negara bersegi satu yang mengaplikasikan peraturan dalam hal konkrit harus memenuhi persyaratan dan prosedur tertentu. Maka dari kedua kasus yang dikemukakan memperlihatkan bahwa ada penambang telaj melalaikan kewajibannya sebagaimana ditentukan dalam perundang-undangan yang berlaku.

Atas dasar hal tersebut, maka paksaan pemerintahan (Bestuursdwang) merupakan upaya preventif dalam penegakan hukum yang diarahkan terhadap kegiatan, baik yang berkaitan dengan pentaatan terhadapundang-undang maupun pentaatan yang berhubungan dengan pesyaratan perizinan, khususnya menyangkut Rencana Pengelolaan Lingkungan ( RKL ) dan Rencana Pemantauan Lingkungan ( RPL) yang telah ditetapkan.

Namun demikian, bila diperhatikan kedua kasus yang merupakan paksaan pemerintahan tersebut terdapat perbedaan dalam penerapannya. Bila Surat Perintah Bupati no. : 545/1662-Ekon/1992 didahului dengan teguran kepada pengusaha yang melakukan pelanggaran, tetapi pada Surat Keputusan Gubernur Kepala Daerah Tingkat I Jawa Barat no. : 540/Sk.983/Distamb/93, tidak disertai dengan teguran.

Hal ini menunjukkan pada kita bahwa pelaksanaan paksaan pemerintahan tidak mutlak harus didahului dengan teguran. Bahkan sebenarnya di dalam aturan-aturan yang ada, tidak selamanya teguran sebagai sanksi administratif diatur, karena dipandang mengikut pada paksaan pemerintahan sebagi konsekuensi pertimbangan asas-asas umum pemerintahan yang baik.

Sejalan dengan pendapat di atas, N. M. Speit dan J. B. J. M. ten Berge menyebutkan:

Pada umumnya ( dikecualikan keadaan-keadaan yang membutuhkan penyelesaian cepat ) organ pemerintahan sebelum melaksanakan paksaan pemerintahan secara nyata, harus mengirimkan peringatan tertulis, sehingga yang dialamatkan diberi kesempatan memperbaiki atau mengakhiri sendiri pelanggaran atas norma hukum itu.(Spelt, N.M. dan Tan Berge, h.75).

Dengan bertitik tolak dari keadaan tersebut, menunjukkan pada kita bahwa penerapan bestuursdwang merupakan wewenang pemerintahan yang mandiri, artinya untuk melaksanakan paksaan pemerintahan tidak membutuhkan kuasa dari organ lain, khususnya badan peradilan. Konsekuensinya pemerintah pada dasarnya mempunyai kebebasan untuk menentukan sendiri diterapkan atau tidaknya paksaan pemerintahan sebagi sanksi atas pelanggaran. Ini berarti pakaan pemerintahan 
sebenarnya merupakan wewenang diskresi .

Berdasarkan realitas tersebut mak sebagi wewenang diskresi, pemerintah tidak memiliki kebebasan penuh dalam menerapkan paksaan pemerintahan, tetapi harus didasarkan pada ketentuan undang-undang ( rechtmattigeheid) serta asas-asas umum pemerintahan yang baik (doelmatigeheid).

\section{Akibat Hukum Pelaksanaan Bestuursdwang bagi Para Pihak yang Dirugikan}

Bila diperhatikan praktik pelaksanaan bestuursdwang sebagaimana dikemukakan sebelumnya, menunjukkan pada kita bahwa paksaan pemerintahan adalah wewenang diskresi, dan merupakan beschikking yang dapat diuji melalui Peradilan tata Usaha Negara apabila seseorang atau badan hukum perdata merasa kepentingannya dirugikan akibat timbulnya keputusan tat usaha negara tersebut.

Tentunya dalam mengajukan gugatan tersebut, harus disertai alasan-alasan :

a. melanggar suatu ketentuan peraturan perundang-undangan;

b. melanggar larangan de'tournement de pouvoir;

c. merupakan suatu tindakan hukum yang melanggar larangan willekeur;

d. melanggar salah satu asas-asas umum pemerintahan yang baik. (Indroharto; 1993 ; h.52)
Dalam hal demikian, tidak jarang terjadi sengketa yang diakibatkan oleh tindakan-tindakan administrasi negara yang berupa penyimpanganpenyimpangan yang melawan hukum dan mendatangkan kerugian bagi yang terkena ketetapan tersebut, dalam hal ini rakyat ( seseorang atau badan hukum perdata).

Bertalian dengan kenyataan tersebut, bila dihubungkan dengan kedua kasus yang dikemukakan baik Surat Perintah Bupati KDH Tingkat II Sukabumi no. : 545/1662-Ekon/1992 mau pun Surat Keputusan Gubernur KDH Tingkat I Jawa Barat no. : 540/ SK.983/Distamb/93 membawa konsekunsi kemungkinan digugatnya beschikking tersebut melalui Peradilan tata Usaha Negara. Namun bila diperhatikan kedua kasus posisi tersebut, ternyata tidak memenuhi kriteria objek sengketa, yakni sifat individual dan konkrit sebagai keputusan tata usaha negara :

Keputusan Tata usaha Negara adalah suatu penetapan tertulis yang dikeluarkan oleh Badan atau Pejabat Tata Usaha Negara yang berisi tindakan hukum Tata usaha Negara yang berdasarkan peraturan perundang-undangan yang berlaku, yang bersifat konkrit, individual dan final yang menimbulkan akibat hukum bagi seseorang atau badan hukum perdata.(UU. No. 5 Th. 1996., Pasal 1 angka 3).

Dari konstelasi yang demikian, timbul pertanyaan apakah dengan tidak dipenuhinya unsur tersebut, maka beschikking itu tidak dapat diuji oleh 
hakim peradilan tata usaha negara?.

Disinilah letak peranan hakim menjadi penemu hukum, pembentuk hukum, pembaharu hukum dan penegak hukum sebagai benteng keadilan. Dalam keadaan demikian dapat dibedakan antara hukum positif materiil dan hukum positif formal.(Sjachran Basah;1992;h.4)

Berdasarkan hal tersebut, menurut hemat penulis, Baik Surat Perintah Bupati KDH Tingkat II Sukabumi no. : 545/1662-Ekon/1992 mau pun Surat Keputusan Gubernur KDH Tingkat I Jawa Barat no, : 540/SK.983/Distamb/93 dapat digugat melalui Peradilan Tata Usaha Negara oleh para pengusaha tambang yang merasa dirugikan akibat keputusan tersebut sesuai dengan Pasal 53 ayat 2 huruf $C$ yang menyebutkan salah satu alasan gugatan adalah Badan atau Pejabat Tata Usaha Negara pada waktu mengeluarkan atau tidak mengeluarkan keputusan sebagaimana dimaksud dalam ayat (1) setelah mempertimbangkan semua kepentingan yang tersangkut dengan keputusan itu seharusnya tidak sampai pada pengambilan atau tidak pengambilan keputusan tersebut.

Realitas ini sejalan dengan prinsip negara hukum materiil yang kita anut, yang membawa konsekuensi dalam pertimbangan putusan hakim atas Keputusan Tata Usaha Negara tidak hanya mendasarkan pada rechtmatigeheid, tetapi juga menyangkut doelmatigeheid termasuk asas-asas umum pemerintahan yang baik seperti asas keseimbangan, fair play, asas kecermatan dan sebagainya.

Oleh sebab itu, hakim peradilan administrasi negara sepatutnya tidak hanya menggunakan interpretasi formal dalam menguji keputusan tata Usaha Negara, karena interpretasi formal saja tidak cukup menjaring konsep keputusan yang sifatnya individual. Bila hal ini yang diterapkan akan membawa preseden bagi para pejabat Tata Usaha Negara untuk membuat keputusan yang tidak ditujukan kepada orang atau badan hukum perdata tertentu guna menghindari gugatan dimuka peradilan Tata Usaha Negara.

Pada akhirnya dengan perwujudan yang demikian, maka administrasi negara dalam melakukan tindakannya akan lebih berhati-hati dan bagi warga masyarakat akan merasa terayomi dengan ditegakkannya hukum dengan sebaik-baiknya, yang pada gilirannya akan dapat menciptakan pemerintahan yang bersih dan berwibawa sesuai dengan falsafah bangsa Indonesia yaitu Pancasila dan landasan konstitusional UUD 1945.

\section{PENUTUP}

Bertitik tolak dari uraian yang telah dikemukakan, maka sebagai penutup dari tulisan ini penulis mengemukakan beberapa kesimpulan dan saran-saran :

Adapun yang menjadi kesimpulan sesuai dengan topik bahasan makalah ini adalah : 
1. Penerapan paksaan pemerintahan Bestuursdwang ) adalah merupakan wewenang diskresi dari pejabat tata usaha negara sebagai instrumen administratif yang dapat digunakan berdasarkan pertimbangan-pertimbangan tertentu, khususnya dalam konteks perizinan apabila berbagai persyaratan mau pun ketentuan perundang-undangan tidak dipatuhi oleh pemegang izin, seperti halnya persyaratan pemeliharaan lingkungan hidup. Hal ini antara lain terlihat dari bestuursdwang yang diterapkan dalam Surat Perintah Bupati KDH Tingkat II Sukabumi no. ; 545/1662-Ekon/1992 dan Surat Keputusan Gubernur KDH Tingkat I Jawa Barat no. : 540/SK.983/Distamb/93 (terlampir).

2. Sebagai wewenang diskresi, maka bestuursdwang yang digunakan untuk upaya preventif penegakan hukum ( termasuk hukum lingkungan ) dapat digugat oleh seseorang atau badan hukum perdata yang merasa dirugikan akibat putusan tersebut melalui peradilan Tata Usaha Negara dengan alasan sebagaimana disebutkan dalam Pasal 53 Undang-Undang no. 5 Tahun 1986, termasuk penerapan asas-asas umum pemerintahan yang baik Bila dihubungkan dengan kedua kasus sebagaimana disebutkan diatas, maka berdasarkan ketentuan Pasal 53 Undang-Undang no. 5 Tahun 1986 serta asasasas umum pemerintahan yang baik, bestuursdwang tersebut dapat diuji loeh hakim
Peradilan Tata Usaha Negara.

Berdasarkan kesimpulan tersebut, maka diperoleh saran-saran sebagai berikut :

1. Memperhatikan akibat hukum penerapan bestuursdwang yang sangat kompleks dan untuk terbinanya pemerintahan yang bersih dan berwibawa, diharapkan pejabat administrasi negara harus mempertimbangkan baik aspek doelmatigeheid sebelum sampai pada pengambilan keputusan penerapan paksaan pemerintahan.

2. Kepada warga masyarakat, khususnya yang memperoleh izin usaha agar senantiasa mentaati ketentuan perundang-undangan yang berlaku serta prosedure dan persyaratan yang telah ditetapkan, sehingga dapat dihindari berbagai pelanggaran yang pada gilirannya dapat merugikan masyarakat bangsa dan negara.

3. Akhirnya kepada pemerintah diharapkan guna mewujudkan pembangunan yang berkelanjutan, dapat melakukan tindakan tegas kepada pemegang izin yang melanggar ketentuan hukum, khususnya hukum lingkungan, baik melalui instrumen hukum perdata, hukum pidana maupun instrumen hukum administrasi.

\section{DAFTAR PUSTAKA}

Bachsan Mustafa, Pokok-pokok Hukum Administrasi Negara, PT. Citra AdityaBakti, Bandung, 1990. 
Djenal Hoesen Koesoemahatmadja, Pokok-pokok

Hukum Tata Usaha Negara, Alumni, Bandung, 1979.

Daud Silalahi, M., Hukum Lingkungan Dalam Sistem Penegakan Hukum Lingkungan Indonesia, Alumni, Bandung, 1992.

Hamzah, A., Penegakan Hukum Lingkungan, Arikha Media Cipta, Jakarta, 1995.

Indroharto, Usaha Memahami Undang-undang tentang Peradilan Tata Usaha Negara, Buku I, Sinar Harapan, Jakarta, 1994.

Usaha Memahami Undangundang tentang Peradilan Tata Usaha Negara, Buku II, Sinar Harapan, Jakarta, 1993.

Philipus M. Hadjon, dkk., Pengantar Hukum Administrasi Negara Indonesia (Introduction to the Indonesian Administrative Law), Gadjah Mada University Press, Yogyakarta, 1993.

Rochmat Soemitro, Peradilan Tata Usaha Negara, PT. Eresco, Bandung, 1987.

Siti Sundari Rangkuti, Kajian Peraturan Perundang-undangan Lingkungan Indonesia (An Overview of Indonesian Environmental Legislation), makalah pada Penataran Hukum Administrasi dan Hukum Lingkungan Kerjasama Hukum Indonesia Belanda Fak. Hukum UNAIR, Surabaya, 1992.
Sjachran Basah, Tiga Tulisan tentang Hukum, Armico, Bandung, 1986.

Perlindungan Hukum terhadap Sikap tindak Administrasi Negara, Alumni, Bandung. 1992.

Pengadilan Dalam Lingkungan
Peradilan Administrasi (HAPLA),
Rajawali Pers, Jakarta, 1992.
makalah pada Penataran Hukum
Administrasi dan Hukum Lingkungan
Kerjasama Hukum Indonesia - Belanda,
Fak. Hukum UNAIR, Surabaya, 1992.

Spelt, N.M., dan ten Berge, Pengantar Hukum Perizinan, Yuridika, Surabaya, 1993.

Utrecht E. dan Moh. Saleh Djindang, Pengantar Hukum Administrasi Negara Indonesia, Sinar Harapan, Jakarta, 1990. 